\title{
Life Cycle Assessment of New Oxy-Fuels from Biodiesel-Derived Glycerol
}

\author{
Francesco Asdrubali ${ }^{1, *}$, Franco Cotana ${ }^{1}$, Federico Rossi ${ }^{1}$, Andrea Presciutti ${ }^{1}$, \\ Antonella Rotili ${ }^{1}$ and Claudia Guattari ${ }^{2}$
}

1 Inter-University Research Center on Pollution and Environment "Mauro Felli" (CIRIAF), University of Perugia, Via G. Duranti 63, Perugia 06125, Italy;

E-Mails: franco.cotana@unipg.it (F.C.); federico.rossi@unipg.it (F.R.); andrea.presciutti@unipg.it (A.P.); rotili.unipg@ciriaf.it (A.R.)

2 Department of Engineering, University of Roma TRE, Via della Vasca Navale 79, Rome 00146, Italy; E-Mail: claudia.guattari@uniroma3.it

* Author to whom correspondence should be addressed; E-Mail: francesco.asdrubali@unipg.it; Tel.: +39-075-585-3716.

Academic Editor: Arthur J. Ragauskas

Received: 19 November 2014 / Accepted: 11 February 2015 / Published: 27 February 2015

\begin{abstract}
Biodiesel is obtained by the process of transesterification of vegetable oils and animal fats and crude glycerol is the main by-product of the biodiesel manufacturing chain. As a result glycerol production has rapidly increased in the last decades. This work focuses on the development and the validation of a process to convert biodiesel-derived glycerol into a fuel for internal combustion engines. In order to obtain a higher conversion efficiency it was necessary to convert crude glycerol to tert-butyl ethers by means of an etherification process that was carried out in the laboratory. Then the obtained glycol-ethers mixture (GEM) was blended with a commercial diesel fuel to improve its thermal efficiency. In this paper a life cycle analysis for these GEM/diesel blends was carried out using a Life Cycle Assessment (LCA) methodology, in order to evaluate the environmental impacts of these new oxy-fuels; from GEM production to GEM use as an additive for diesel fuel. The LCA results highlight that the use of these new oxy-fuels in diesel engines can lead to an effective reduction in terms of greenhouse gases emissions throughout the entire life cycle.
\end{abstract}

Keywords: biodiesel; glycerin; additive; Life Cycle Assessment 


\section{Introduction}

The conversion of biomass into energy is experiencing a fast and growing market, and many different technologies are being developed in order to increase energy efficiency and reduce environmental impacts. The use and valorization of bio sub-products of other technological processes is extremely interesting from both the economic and environmental point of view [1-5].

Pushed by the great interest in renewable energies and biomass in particular [6,7], and despite the uncertain political context in the European Union, biofuel consumption is growing, reaching almost 14.4 million toe in 2012. The trend is confirmed by Eurobserv'ER Barometer 2013: the increase was 2.9\% between 2011 and 2012 [8]. However, OECD-FAO [9] forecasts a biodiesel production growth trend of 9.1\% in Western Europe in the period 2013-2022. During the same time OECD-FAO expects a worldwide growth of biodiesel consumption greater than $4.9 \%$. Faster growth of biodiesel use is expected in the European Union by 2022 as a result of the Renewable Energy Directive (RED).

This consumption and production growth of biodiesel results in a significant surplus of glycerol. Glycerol is, in fact, the principal byproduct obtained in the biodiesel transesterification reaction. In general, the production of $100 \mathrm{~kg}$ of biodiesel creates $10 \mathrm{~kg}$ of crude glycerol.

As a consequence the market price of glycerol quickly decreased, so research has been focusing on the development of new technologies for using glycerol, in order to improve the biodiesel chain business. Various methods for disposal and utilization of crude glycerol have been attempted, including combustion, composting, anaerobic digestion, animal feeds, and thermochemical/biological conversions to value-added products. Fangxia et al. [10] highlighted that one of the best ways to employ crude glycerol from biodiesel is in the animal feed sector because of the increase in the price of corn compared with crude glycerol derived from biodiesel production. Glycerol [11], in fact, has high absorption rates and is a good energy source. Once absorbed, it can be converted in the liver of animals to glucose for energy production by the enzyme glycerol kinase. Furthermore, the use of glycerol as a source of heat, together with the use of rape cake as a feed stock for animals, proved to be a sustainable system, resulting in Greenhouse Gases (GHG) emission savings of 75\% [12]. Glycerol is also extensively used in the cosmetic and pharmaceutical industries, although the use of crude glycerol is limited due to the presence of impurities such as methanol, salts, and fatty acids [13]. Several examples of chemical modification of crude glycerol have been reported: etherification of biodiesel-derived glycerol with pure ethanol over different heterogeneous catalysts was investigated [14]; it was also demonstrated that the esterification of glycerol with acetic acid to yield glycerine acetates results in a valuable transportation fuel additive [15]. A second way is a thermochemical/biological conversion of crude glycerol. In [16] the authors report a wide variety of high-value products derived from the microbial conversion of crude glycerol. In addition, Luna et al. [17] proposed a new biofuel which was obtained by the incorporation of glycerol as a monoglyceride in a FAME composition and this could reduce the waste glycerol production.

One of the most interesting ways to employ glycerol from the energy point of view is the synthesis of oxygenated compounds, such as glycerol ethers, by an etherification process with alcohols or short-chain olefins.

In the recent years, the use of glycerol derivatives as fuel additives for diesel fuel, biodiesel fuel and gasoline was investigated [18,19]. Moreover, experimental investigations and engine experiments 
evidenced that the use of glycerol ethers as oxygenate additives for diesel engines can reduce emissions and improve thermal efficiency [20-23].

Eaton et al. proposed to burn glycerol-diesel emulsions to improve glycerol combustion [21]. Two glycerol-diesel emulsions at $10 \%$ vol. and $20 \%$ vol. glycerol were burned in a diesel engine and they were compared with ultra lowsulphur diesel (ULSD) combustion; particulate matter (PM) emissions were reduced by $25 \%-50 \%$, respectively.

The properties of glycerol tertiary butyl ethers (GTBEs) were examined by Di Serio [23] and Lovestead et al. [22]; results showed that the mixture of glycerol ethers can be used directly as a diesel additive.

Finally, a mixture of diesel fuel and GTBEs at 10\% vol. was burned in a single-cylinder research engine by Beatrice et al. [20] and engine experiments evidenced that unburned compounds were reduced using a Glycol-Ether Mixture (GEM, a mixture of glycerol di- (DBG) and tri-tert-butyl (TBG) ethers of glycerol) blend; furthermore, these results evidenced the compatibility of GEM with fuel standards.

Recent research papers [24-27] show how a blend of GEM can be employed as an excellent additive for diesel, being characterized by compatible physical and chemical properties in terms of flash point, viscosity and cetane number. In addition, the burning of GEM-diesel mixtures can ensure reduced pollutant and particulate matter emissiond thanks to their oxygen content. Therefore, glycerol derived oxy-fuels can be an interesting alternative to substitute for conventional fuels.

Within this context, a research project funded by the Italian Ministry for Agriculture and Forestry started in 2010. The aim of project was to improve the energy valorization of glycerol as a product of the biodiesel chain, and in particular, to complete the validation of the GEM as a fuel in experimental engine tests, and also through a Life Cycle Assessment (LCA).

The LCA methodology is a useful tool to evaluate the environmental impacts of the entire life cycle of products, from raw material extraction to waste disposal. International studies have assessed the LCA methodology's reliability and effectiveness for evaluating improvements in terms of sustainability and GHG savings by means of by-product utilization [12].

In particular, LCAs of biofuels can evidence both advantages and disadvantages, especially if biofuels are suitable and cost-effective alternative to fossil fuels [28,29]. Since biofuels derive from biomass exploitation, they are considered carbon neutral during direct combustion.

The comparison between biodiesel, diesel and gasoline as automotive fuels shows that biodiesel fuel contributes less to climate change and fossil energy depletion with respect to the other ones, but it was observed that biodiesel caused more damage to the natural ecosystem than fossil fuels. The life cycle impacts of biodiesel were mainly due to inorganic respiratory effects, acidification and eutrophication caused by $\mathrm{NO}_{\mathrm{x}}$ emissions [30]. Other LCA studies evidenced the same environmental aspects for other alternative fuels, such as bio-ethanol or bio-methanol [31,32].

Therefore, the aim of this paper is the evaluation by means of a LCA assessment of the impact of GEM/diesel blend combustion on human health, quality of ecosystems and on resources compared with diesel and alternative fuels. 


\section{Methodology}

The Life Cycle Assessment (LCA) methodology is a standardized method developed by Society of Environmental Toxicology and Chemistry (SETAC) and the International Organization for Standardization since the early ' $90 \mathrm{~s}$. This analysis encompasses the entire life cycle of goods or services in order to assess potential or avoided environmental impacts caused by exchanges between the examined system and the environment. Thus, it allows analysts to support decisions relative to process design or optimize a process chain on the basis of a life cycle's environmental sustainability.

In accordance with the general framework provided by the ISO standards 14040 and 14044 [33,34], the structure of a LCA is subdivided in four parts:

- Goal and scope definition;

- Life Cycle Inventory;

- Life CycleAssessment;

- Interpretation of the results.

Defining goal and scope means to declare the aim of the study and the limits of examined system. It is important to define system boundaries because all the environmental burdens outside are ignored. Therefore it is necessary to specify assumptions, methodological approaches, boundary conditions and data sources as well as the functional unit chosen. This is a reference unit that represents the function performed by system under study: all inflows and outflows of each life cycle stage must be normalized with respect to that quantity (i.e., one kilogram of product). Furthermore, functional unit allows to make comparison analysis between different but functionally equivalent systems.

All relevant processes were identified and substances and energy flows across system boundaries were quantified; data were collected and validated.

On the basis of life cycle inventory results, environmental impacts were calculated by applying appropriate evaluation methods. The outcomes were expressed by single index or category indicators.

In this work the Eco-indicator $99(\mathrm{H})$, the Cumulative Energy Demand (CED) and the Intergovernmental Panel on Climate Change (IPCC GWP 2007) methods were considered [35].

The Eco-indicator 99 damage factors for substances and resources of life cycle inventory were calculated according to eleven impact categories (Carcinogens, Respiratory organics, Respiratory inorganics, Climate change, Ozone depletion, Radiation, Acidification and eutrophication, Ecotoxicity, Land use and Mineral and fossil resources depletion). After normalization and weighting, environmental impacts were grouped in three damages categories: damages to Human Health (HH), Ecosystem Quality (EQ) and Resources depletion (R). Each environmental score was expressed in Eco-indicator points (Pt); Eco-scores allow to make comparison between categories as well as different product systems [36].

Uncertainties in LCA were considered according to different cultural perspective (Egalitarian, Hierarchist, Individualist). In this study the Hierarchist perspective $(\mathrm{H})$ was considered as the default perspective in the Eco-indicator method [36].

The CED method evaluates all primary energy requirements throughout the entire life cycle of a product or service including both direct and indirect use of energy. CED indicators were measured in Mega Joule equivalents of primary energy (MJ-eq). 
CED-value was split into two main categories (non-renewable and renewable resources) subdivided in eight sub-categories (fossil, nuclear, primary forest, biomass, wind, solar, geothermal, water).

The IPCC GWP method evaluated greenhouse gas emissions due to anthropogenic activities in calculating the global warning potential (GWP). The GWP indicator is an index for representing the contribution to global warming of a gaseous substance released into the atmosphere compared to the impact of one kilogram of carbon dioxide. The GWP indicator was measured in kilograms of $\mathrm{CO}_{2}$ equivalents ( $\mathrm{kg} \mathrm{CO}_{2}$-eq) and three time horizons are considered (20, 50, 100 years). In this study 100 years of time horizon was chosen.

The life cycle analysis was carried out with SimaPro v.7.3 software (Prè Consultants, Amersfoort, The Netherlands). In addition, data was gathered from the Ecoinvent database in case of a lack of information about a life cycle's processes [37].

\section{LCA Application}

\subsection{Goal and Scope}

The goal of this LCA study was to investigate the potential environmental impacts of using the new oxygenated fuels produced by conversion of glycerol. The aim was to evaluate the effectiveness of the benefits they could offer to biofuels and bioenergy systems, especially to the biodiesel production chain. Crop cultivation, transport, oil extraction and transesterification were the processes included in the biodiesel production, as shown in Figure 1. After the transesterification reaction, crude glycerol was extracted and refined to achieve the desired grade of purity [26,38,39]. It was purified to be marketed and used in industrial applications.

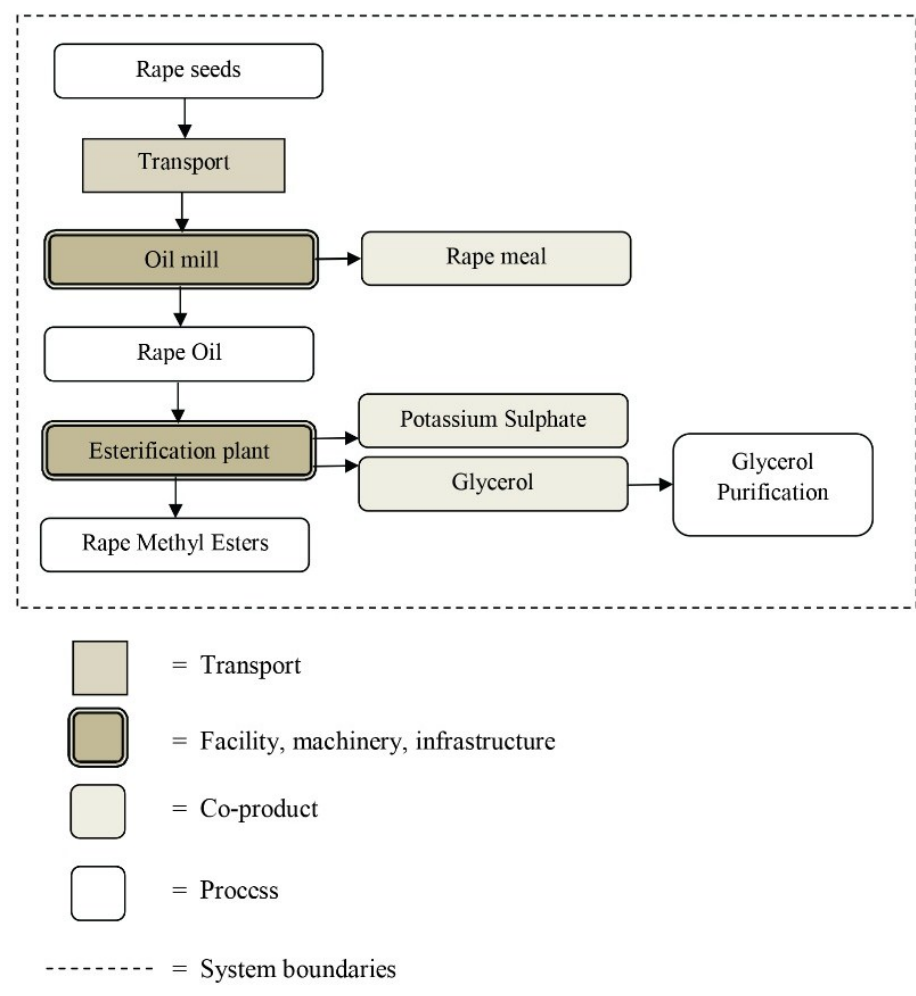

Figure 1. Flowchart of biodiesel (rape methyl esters) and glycerol production from rape seed oil at a transesterification plant. 


\subsection{System Boundaries}

The oxygenated fuels life cycle was subdivided into three main subsystems: the production process of the glycerol ethers mixture (GEM) used as fuel additive; the blending of GEM with a commercial diesel fuel and the final use in internal combustion engine; Figure 2 shows a flowchart of the life cycle processes involved; only relevant processes were included in the system boundaries.

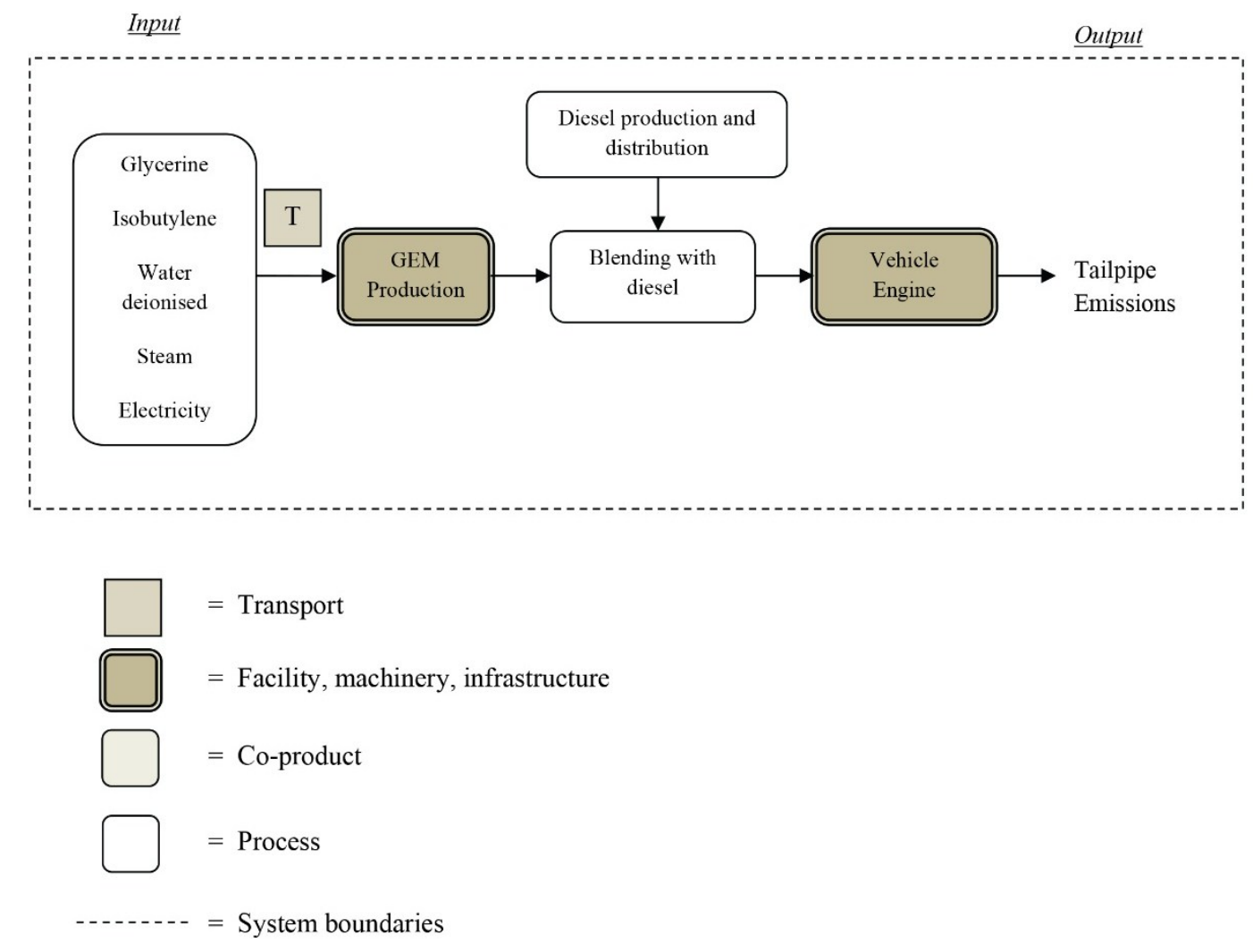

Figure 2. Flowchart of GEM production and consumption and system boundaries.

\subsection{Functional Unit}

The functional unit of the overall analysis is one kilometer $(\mathrm{km})$ driven by a Euro V passenger car; all input and output flows were therefore referred to it.

\subsection{Allocation}

Processes can generate multiple output streams and it was necessary to use an allocation method to split the environmental burdens between co-products. The co-products can be allocated according to mass allocation (based on mass outputs), energy allocation (based on energy content), economic allocation (based on market value) or substitution method (credits due to avoided processes) [33].

In this study, glycerol was co-produced with biodiesel by the transesterifcation process and environmental burdens were shared between biodiesel and crude glycerol. Allocation on market values basis was performed because of remarkably different market prices of biodiesel and the glycerol by-product [26,39]. A share of $12.9 \%$ of the total environmental impact relative to the transesterification process was assigned to biodiesel derived-glycerol, according to [39]. 


\subsection{Inventory Analysis}

\subsubsection{GEM Production}

The system described in this section is the GEM production process by glycerol etherification; the GEM production on large scale is still under development $[11,25,40]$. To identify and quantify the mass and energy flows required for GEM production, the adopted production stage in this LCA study was the reaction between glycerol and isobutylene (IB) carried out in the laboratory. Afterward, scale factors were applied to laboratory values to extend them on a large scale. In particular the etherification reaction between anhydrous glycerol (purity $\geq 99.5 \%$ ) and isobutylene on an ion-exchange dry resin (a cationic resin) used as a solid acid catalyst was considered [41,42].

Etherification was carried out in the liquid phase at a temperature of 343 Kelvin and autogenous pressure in a stainless steel batch reactor with a stirring frequency of 1,200 rpm. The reactor was fed with glycerol ( $28 \%$ by weight of the total mass of reactants) and catalyst ( $2 \% \mathrm{wt}$.). Then liquid IB (69\% wt.) was added into the reactor using a nitrogen flow as carrier. After the appropriate reaction time a mixture of mono-ethers, di-ethers and tri-ether was produced (about $77 \%$ wt. of the initial input) along with other compounds $(21 \% \mathrm{wt}$.), while the catalyst $(2 \% \mathrm{wt}$.) was extracted and recycled back to the reactor. The reaction mixture was cooled to room temperature in an ice-bath to condense the gas phase compounds; the MTBG were less soluble in diesel fuel therefore they were extracted with water in a decanter placed after the reactor and they were reused for a subsequent reaction. Finally, the reaction mixture was passed through a distillation column to separate GEM (about 90\% wt. of the final output) from other unconverted compounds $(10 \% \mathrm{wt}$.).

The following simplified Equations (1)-(3) describe the reaction chain between glycerol $(\mathrm{G})$ and IB forming two mono-tert-butyl glycerol ethers (MTBG), two di-tert-butyl glycerol ethers (DTBG) and one tri-tert-butyl glycerol ether (TTBG):

$$
\begin{gathered}
\mathrm{G}+\mathrm{IB} \rightarrow \mathrm{MTBG} \\
\mathrm{MTBG}+\mathrm{IB} \rightarrow \mathrm{DTBG} \\
\mathrm{DTBG}+\mathrm{IB} \rightarrow \text { TTBG }
\end{gathered}
$$

It was assumed that the glycerol etherification plant was attached to the transesterification plant and there was no transport of glycerin. Transport of isobutylene was considered.

Data related to building and facilities of that etherification plant (required amounts of steel, iron, concrete, etc.) were gathered from the Ecoinvent database, but after verifying that these impacts were lower than the other ones, the environmental impact of the infrastructure has been neglected.

This process was represented by consumptions of materials such as glycerin, isobutylene and water. In addition electricity usage and steam for the chemical process were estimated and data were gathered according to the production process of methyl tert-butyl ether (MTBE), an oxygenated gasoline additive. MTBE is made by etherification reaction between methanol and isobutylene [43].

To model the GEM production process, isobutylene (for the etherification reaction) and water (needed in the extraction phase) were included as mass inputs in agreement with the reaction stoichiometry; data were gathered from a CNR-ITEA (Italy) questionnaire [42]. 
Data for glycerin production were gathered from the literature [39]; isobutylene is a refinery product manufactured by catalytic cracking of naphtha which is a product of petroleum distillation; upstream data were taken from the Ecoinvent database [44].

Since catalyst, MTBG and unconverted compounds were recovered they were not included in the system boundaries. If included in the system they lead to positive environmental burdens.

For the transport isobutylene to the GEM production plant a standard distance of $100 \mathrm{~km}$ by road with a16 t lorry was considered [33].

Using GEM blends or diesel fuels the engine efficiency was constant [20,42]; it was assumed that the GEM blend consumption in terms of energy content was similar to diesel fuel. Diesel consumption was set equal to 2.36 MJ per km according to the Ecoinvent database [39]. Estimated fuel consumption in kilograms (kg) per kilometer are reported in Table 1. Table 2 shows mass and energy balance of the GEM production process; scale factors were applied to convert inputs from the laboratory to an industry scale. Scale factors are reported in Table 3.

Table 1. Fuel consumptions.

\begin{tabular}{ccccc}
\hline Parameter & Unit & GEM10 & GEM20 & Diesel \\
\hline Energy content & $\mathrm{MJ} / \mathrm{kg}$ & $41.3[36]$ & $40.3[36]$ & $43[38]$ \\
Fuel consumption & $\mathrm{MJ} / \mathrm{km}$ & 2.36 & 2.36 & $2.36[29]$ \\
Fuel consumption & $\mathrm{kg} / \mathrm{km}$ & 0.057 & 0.059 & 0.055 \\
\hline
\end{tabular}

Table 2. Inventory data (per km travelled) for GEM production.

\begin{tabular}{ccccl}
\hline Process & Unit & GEM10 & GEM20 & \multicolumn{1}{c}{ Sources } \\
\hline $\begin{array}{c}\text { Input from technosphere } \\
\text { Materials }\end{array}$ & & & & \\
\hline Glycerine & $\mathrm{kg}$ & 0.0036 & 0.0075 & $\begin{array}{l}\text { Derived from GEM chemical reaction } \\
\text { IB }\end{array}$ \\
Water & $\mathrm{kg}$ & 0.0088 & 0.018 & $\begin{array}{l}\text { Derived from GEM chemical reaction } \\
\text { Derived from GEM chemical reaction } \\
\text { Calculation from MTBE production; } \\
\text { data from Literature [43] }\end{array}$ \\
Steam & $\mathrm{kg}$ & 0.0006 & 0.0013 & \\
\hline Energy & 0.0068 & 0.014 & & \\
\hline Electricity & $\mathrm{kWh}$ & $7.98 \times 10^{-5}$ & $1.65 \times 10^{-4}$ & $\begin{array}{l}\text { Calculation from MTBE production; } \\
\text { data from Literature [43] }\end{array}$ \\
\hline Transport & & & & \\
\hline Lorry $>$ 16 t, fleetaverage & $\mathrm{tkm}$ & 0.0009 & 0.0018 & $\begin{array}{l}\text { Standard distance of 100 km; } \\
\text { data from literature [37] }\end{array}$ \\
\hline
\end{tabular}

Table 3. Factors applied to convert inputs for GEM production process.

\begin{tabular}{cccc}
\hline Process & Unit & Scale Factors & References \\
\hline Glycerine & $\mathrm{kg} / \mathrm{kg} \mathrm{GEM}$ & 0.635 & Survey; CNR-ITEA \\
IB & $\mathrm{kg} / \mathrm{kg} \mathrm{GEM}$ & 1.546 & Survey; CNR-ITEA \\
Water deionised & $\mathrm{kg} / \mathrm{kg} \mathrm{GEM}$ & 0.109 & Survey; CNR-ITEA \\
Steam & $\mathrm{kg} / \mathrm{kg} \mathrm{GEM}$ & 1.2 & {$[43]$} \\
Electricityconsumptions & $\mathrm{kWh} / \mathrm{kg} \mathrm{GEM}$ & 0.014 & {$[43]$} \\
\hline
\end{tabular}




\subsubsection{GEM Blending}

After the production phase, GEM was incorporated into petroleum diesel at a concentration of $10 \%$ and $20 \%$ by volume respectively (GEM10 and GEM20). The diesel production and distribution were taken into account in the life cycle boundaries according to data derived from the literature [44].

\subsubsection{GEM Combustion}

Finally, the GEM/diesel blends were burned in the internal combustion engine of an automotive vehicle (diesel vehicle). Fuel consumption to travel one kilometer burning GEM/diesel blends is reported in Table 1. The amount of mass of additive and diesel to blend were calculated on the basis of the respective densities of the alternative fuel and the conventional diesel fuel as shown in Table 4.

Table 4. Inventory data (per km travelled) for GEM blending phase.

\begin{tabular}{ccccc}
\hline Process & Unit & GEM10 & GEM20 & Sources \\
\hline Input from technosphere & & & & \\
\hline Materials & & & & \\
\hline Diesel & $\mathrm{kg}$ & 0.051 & 0.047 & $\begin{array}{l}\text { Estimated from GEM blend density }\left({ }^{*}\right) \\
\text { and fuel consumption }\end{array}$ \\
\hline * Calculations according to the incorporation rate of GEM and the respective densities of GEM and diesel.
\end{tabular}

Tailpipe emissions of the vehicle due to direct combustion of GEM/diesel blends were derived from engine tests, according to [20,42]. The experimental tests were carried out with two GEM/diesel blends, with $10 \%$ and $20 \%$ by volume of GEM, respectively, with a single cylinder diesel research engine for evaluating engine performance under different operating conditions. According to these experimental tests unburned hydrocarbons (HC), carbon monoxide (CO) and particular matter (PM) emissions were reduced despite a slightly increase of nitrogen oxide $\left(\mathrm{NO}_{\mathrm{x}}\right)$ emissions, by burning GEM/diesel blends in comparison with neat diesel fuel combustion. Measured tailpipe emissions are reported in Table 5.

Table 5. Tailpipe emissions.

\begin{tabular}{cccc}
\hline Emissions & Unit & GEM10 & GEM20 \\
\hline $\mathrm{CO}$ & $\mathrm{kg} / \mathrm{kWh}$ & 0.00085 & 0.00069 \\
$\mathrm{HC}$ & $\mathrm{kg} / \mathrm{kWh}$ & 0.00038 & 0.00031 \\
$\mathrm{NO}_{\mathrm{x}}$ & $\mathrm{kg} / \mathrm{kWh}$ & 0.00215 & 0.00203 \\
$\mathrm{PM}$ & $\mathrm{kg} / \mathrm{kWh}$ & 0.000123 & 0.00008 \\
\hline
\end{tabular}

Fuel conversion efficiency of GEM blends $\left(\eta_{\text {fuel }}\right)$ were calculated by Equation $(4)[20,42]$ :

$$
\eta_{\text {fuel }}=\frac{1}{I S F C \times L H V_{\text {GEM blends }}}
$$

where $I S F C$ was specific fuel consumption $(\mathrm{kg} / \mathrm{kWh})$ and $L H V_{\text {GEM blends }}$ were the low heating values of GEM10 and GEM20 blends, respectively, equal to $41.3 \mathrm{MJ} / \mathrm{kg}$ and $40.3 \mathrm{MJ} / \mathrm{kg}$ [42].

Emissions for the combustion phase were estimated per kilometer travelled and reported in Table 6. As shown in Table 6, fossil $\mathrm{CO}_{2}$ emissions were taken into account due to the fossil portion of the GEM 
blends. Fossil $\mathrm{CO}_{2}$ emissions were calculated according to the carbon content of diesel fuel and fuel consumption.

Table 6. Inventory data (per km travelled) for GEM blends combustion in a vehicle engine.

\begin{tabular}{cccc}
\hline Emissions & Unit & GEM10 & GEM20 \\
\hline Output to technosphere & & & \\
\hline Emissions to air & & & \\
\hline $\mathrm{CO}$ & $\mathrm{kg}$ & 0.0031 & 0.0025 \\
$\mathrm{HC}$ & $\mathrm{kg}$ & 0.0014 & 0.0011 \\
$\mathrm{NO}_{\mathrm{x}}$ & $\mathrm{kg}$ & 0.0077 & 0.0072 \\
$\mathrm{PM}$ & $\mathrm{kg}$ & 0.0004 & 0.0003 \\
FossilCO & $\mathrm{kg}$ & $0.16(*)$ & $0.14(*)$ \\
\hline
\end{tabular}

(*) $1 \mathrm{~kg}$ of diesel fuel $\left(\mathrm{C}_{12} \mathrm{H}_{23}\right)$ produces $3.16 \mathrm{~kg} \mathrm{CO}$ according to the stoichiometric coefficients of the chemical reaction with oxygen $\left(\mathrm{O}_{2}\right)$.

The vehicle's life cycle was not included in the system boundaries.

\subsection{Results}

Life cycle impacts were calculated by applying the Eco-indicator $99(\mathrm{H})$ method and they were calculated with the SimaPro v.7.3 software. This evaluation method aggregates environmental impacts in a single score expressed in Eco-indicator Points $(\mathrm{Pt})$, subdivided into 1000 milliPoints (mPt). The highest score is associated to the worst environmental performance. Table 7 shows the results of this methodology for each life cycle stage.

Table 7. Life cycle impacts of diesel/GEM blends expressed in millipoints (mPt) per km travelled (Eco-indicator method).

\begin{tabular}{cccccc}
\hline \multicolumn{2}{c}{ Eco-Indicator } & GEM Production & Blending & Combustion & Total \\
\hline GEM10 & $\mathrm{mPt} / \mathrm{km}$ & 7.96 & 16.21 & 29.21 & 53.37 \\
GEM20 & $\mathrm{mPt} / \mathrm{km}$ & 16.48 & 14.91 & 26.95 & 58.33 \\
\hline
\end{tabular}

In addition, results for the impact categories of Econdicator 99 are shown in Figure 3 (carcinogens, respiratory effects, climate changes, ozone depletion, radiation, acidification and eutrophication, ecotoxicity, land use and fossil resources depletion). Figure 3 shows the percentage contribution of the different impact categories for GEM10 and GEM20.

Finally environmental impacts were grouped into three damage categories: Human Health, Ecosystem Quality and Resources. Results for damage categories are shown in Table 8. 


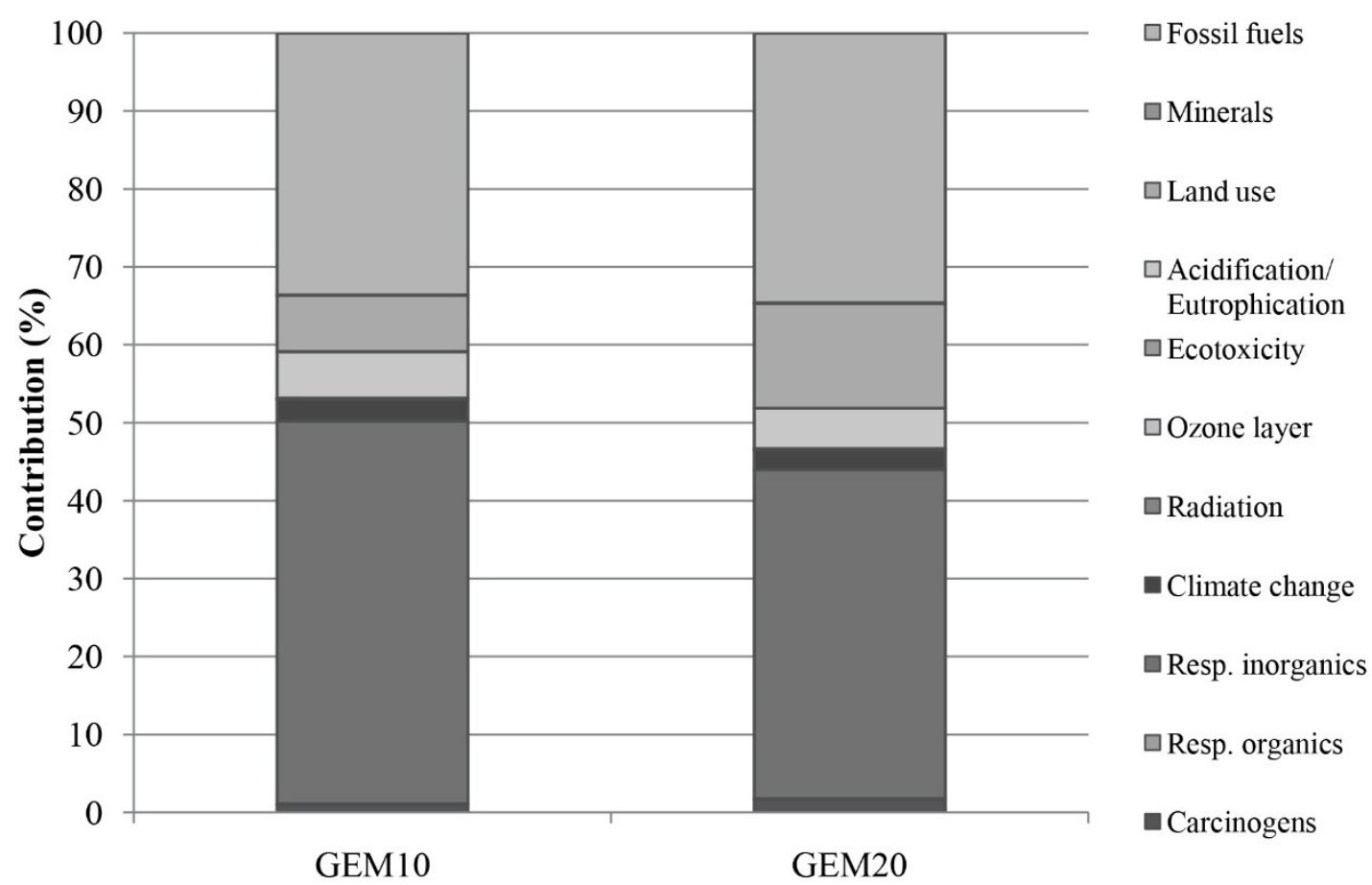

Figure 3. Results for impact categories of GEM10 and GEM20.

Table 8. Damage categories of Eco-indicator $99(\mathrm{H})$ for GEM blends expressed in millipoints $(\mathrm{mPt})$ per $\mathrm{km}$ travelled.

\begin{tabular}{ccccc}
\hline \multicolumn{2}{c}{ Eco-Indicator } & Human Health & Ecosystem Quality & Resources \\
\hline GEM10 & $\mathrm{mPt} / \mathrm{km}$ & 28.30 & 7.10 & 17.96 \\
GEM20 & $\mathrm{mPt} / \mathrm{km}$ & 27.15 & 10.94 & 20.23 \\
\hline
\end{tabular}

On the basis of this environmental analysis, the best environmental profile corresponds to the GEM10 blend.

The Human Health damage category gave the highest score for both blends, as shown in Table 8 . This can be mostly attributed to Carcinogens due to GEM production and Respiratory effects due to the combustion in the vehicle engine. In fact, the major contribution of overall impact is due to the combustion phase for both GEM blends, as shown in Table 7.

To validate and extend these results, GEM blends were compared with other conventional fuels. LCA was performed estimating GWP indicators and CED indicators both for GEM10 and GEM20. In this study the most representative fuels in Europe were investigated and CED and GWP values were calculated and summarized in Table 9. The Table below shows the comparison between GEM blends and fossil and alternative fuels per kilometer driven by a Euro $\mathrm{V}$ passenger car.

It can be observed that GEM 20 presents a slight reduction of life cycle greenhouse gas emissions if compared with diesel or gasoline. This is mainly due to the reduction of soot and unburned gases during the combustion of the GEM blends. These results were also verified by measurements with the test engine [42]. 
Table 9. Indicators of examined fuels.

\begin{tabular}{|c|c|c|c|c|}
\hline Fuel & System & CED (MJ-eq/km) & GWP (kg CO & Source \\
\hline GEM10 & $\begin{array}{l}\text { Production and use of } \\
\text { GEM10 }\end{array}$ & 3.64 & 0.200 & $\begin{array}{l}\text { Calculated by } \\
\text { SimaPro } 7.3\end{array}$ \\
\hline GEM20 & $\begin{array}{l}\text { Production and use of } \\
\text { GEM20 }\end{array}$ & 4.31 & 0.190 & $\begin{array}{c}\text { Calculated by } \\
\text { SimaPro } 7.3\end{array}$ \\
\hline Diesel & $\begin{array}{l}\text { Production and use of } \\
\text { diesel fuel }\end{array}$ & 2.91 & 0.201 & $\begin{array}{c}\text { Ecoinvent database; } \\
\text { Calculated by } \\
\text { SimaPro } 7.3\end{array}$ \\
\hline Gasoline & $\begin{array}{l}\text { Production and use of } \\
\text { gasoline }\end{array}$ & 2.69 & 0.203 & $\begin{array}{l}\text { Derived from } \\
\text { Literature [45] }\end{array}$ \\
\hline RME5 & $\begin{array}{l}\text { Production and use of } \\
\text { Rape seed methyl } \\
\text { esters blend }\end{array}$ & 3.11 & 0.210 & $\begin{array}{c}\text { Ecoinvent database; } \\
\text { Calculated by } \\
\text { SimaPro } 7.3\end{array}$ \\
\hline $\begin{array}{l}\text { Biodiesel from } \\
\text { recycledoil }\end{array}$ & $\begin{array}{l}\text { Production and use of } \\
\text { Biodiesel from } \\
\text { recycled oil at } \\
10 \% \text { diesel }\end{array}$ & 1.77 & 0.148 & $\begin{array}{l}\text { Derived from } \\
\text { Literature [45] }\end{array}$ \\
\hline E5 & $\begin{array}{l}\text { Production and use of } \\
\qquad 5 \% \text { vol. } \\
\text { Ethanol/gasoline blend }\end{array}$ & 3.73 & 0.239 & $\begin{array}{c}\text { Ecoinvent database; } \\
\text { Calculated by } \\
\text { SimaPro } 7.3\end{array}$ \\
\hline ETBE/gasoline & $\begin{array}{l}\text { Production and use of } \\
15 \% \text { vol. } \\
\text { ETBE/gasoline blend }\end{array}$ & 3.58 & 0.229 & $\begin{array}{c}\text { Ecoinvent database; } \\
\text { Calculated by } \\
\text { SimaPro } 7.3 .3 \\
\end{array}$ \\
\hline
\end{tabular}

\section{Discussion}

LCA of GEM blends were performed through three evaluation methods (Eco-indicator 99 method, CED method and IPCC method). The Eco-indicator 99(H) method showed that the main contributing phase of GEM10 was the combustion phase (54\% of overall impact) followed by the blending phase (30\%) and GEM production phase (15\%). A contribution of $47 \%$ of the overall impacts of GEM20 was due to its combustion phase, $25 \%$ was due to blending with diesel and $28 \%$ was due to GEM production. In addition, results obtained showed that about $90 \%$ of the overall impact of both blends could be attributed to:

- Carcinogens due to GEM production;

- Land use due to glycerol production;

- Fossil fuels depletion due to blending with fossil diesel;

- Responsibility effects, acidification/eutriphication and climate change due to the combustion phase.

Damages to Human Health were responsible for $53 \%$ of the global impact of GEM10, damages to Ecosystem Quality accounted for $13 \%$ and damages to Resources accounted for $33 \%$. In addition, about $46 \%$ of the overall impact of GEM20 was due to damages to Human Health, $18 \%$ due to damages to Ecosystem Quality and 34\% due to Resources depletion.

Furthermore, CED values of GEM10 and GEM20 was estimated respectively equal to 3.64 and 4.31 MJ-eq $/ \mathrm{km}$. GWPs were estimated equal to $0.200 \mathrm{~kg}$ and $0.190 \mathrm{~kg}$ of $\mathrm{CO}_{2}$-eq per kilometer driven 
by a passenger car. In addition, GEM blends were compared with pure conventional diesel fuel and other alternative fuels (rape seed methyl esters blend, ethanol blend and ETBE blend).

High primary energy requirements were evaluated for the entire life cycle of GEM10 and GEM20 and these results were reasonable because the upstream processes, such as the glycerol production process, need high energy flows. However, it is interesting to note that greenhouse gas emissions decreased using GEM20 with respect to the other investigated fuels, except for biodiesel blend derived from recycled oil.

Furthermore, the positive environmental benefits of glycerol derived oxy-fuels were also confirmed through an experimental investigation carried out by the Istituto Motori [36]; these results evidenced a pollutant emissions reduction respect to conventional fuel.

\section{Conclusions}

Worldwide biodiesel production is projected to grow and consequently research is focusing on new alternatives for using the crude glycerol produced as a result of biodiesel transesterification. New research has developed a diesel additive (Glycol-Ether Mixture: GEM), synthesized from crude glycerin and isobutylene, that has good engine combustion performance.

The aim of this paper was to analyze the GEM-diesel blend with the LCA approach, in order to evaluate the impacts of its use compared with conventional fuels. LCA of GEM10 and GEM20 were performed by the Eco-indicator 99(H) method, CED method and IPCC GWP 2007 method.

In terms of environmental impacts, high damages to human health were attributed to the combustion phase and high damages to Ecosystem Quality were due to the GEM production phase for both GEM10 and GEM20. However, these results could change and the damages could be reduced if both process were enhanced and implemented by carrying out further research. Nevertheless, GEM blends used as automotive fuels, in particular GEM20, can reduce greenhouse gas emissions throughout the entire life cycle. These obtained results could be extremely significant for the achievement of the $10 \%$ renewable energy target for the EU transportation sector by 2020, as mandated by the Renewable Energy Directive.

\section{Acknowledgments}

The authors would like to thank the Italian Ministry of Agriculture, Food and Forestry for funding this work within the "TERVEG" Project (National funding call "Bando bioenergetico DM 246/2007, GU No. 94" del 27/11/2007). The Authors are also indebted with Francesco Frusteri from CNR-ITAE who provided the data concerning GEM production.

\section{Author Contributions}

Francesco Asdrubali, coordinator of the research project, supervised all the activities reported in the paper and gave suggestions on the organization of the paper. Andrea Presciutti collected data for life cycle inventory, Claudia Guattari make substantial contributions to define the state of art of the use of crude glycerol, Antonella Rotili contributed to inventory analysis and evaluated LCA impacts. Andrea Presciutti, Claudia Guattari and Antonella Rotili wrote the first draft of the paper. Franco Cotana and Federico Rossi participated in the phase of comparison with conventional fuels and revised critically 
LCA results. All the authors participated in revising the article and modified the paper after reviewers' comments. All the authors gave final approval of the version to be submitted.

\section{Conflicts of Interest}

The authors declare no conflict of interest.

\section{References}

1. Messineo, A.; Volpe, R.; Asdrubali, F. Evaluation of net energy obtainable from combustion of stabilised olive mill by-products. Energies 2012, 5, 1384-1397.

2. Cotana F.; Belardi, P.; Manciola, P.; Tamagnini, C.; Materazzi, A.L.; Fornaciari, M.; Petrozzi, A.; Pisello, A.L.; Cavalaglio, G.; Coccia, V.; et al. TIAR: Renewable energy production, storage and distribution; a new multidisciplinary approach fort the design of rural facility. Energy Procedia 2014, 45, 323-332.

3. Rossi, F.; Filipponi, M.; Castellani, B. Investigation on a novel reactor for gas hydrate production. Appl. Energy 2012, 99, 167-172.

4. Rossi, F.; Nicolini, A. Ethanol reforming for supplying molten carbonate fuel cells. Int. J. Low-Carbon Technol. 2013, 8, 140-145.

5. Cotana, F.; Rossi, F.; Nicolini, A. A new geometry high performance small power MCFC. J. Fuel Cell Sci. Technol. 2004, 1, 25-29.

6. International Energy Agency (IEA). World Energy Outlook 2013; IEA: Paris, France, November 2013.

7. Moncada, G.; Asdrubali, F.; Rotili, A. Influence of new factors on global energy prospects in the medium term: Comparison among the 2010, 2011 and 2012 editions of the IEA's World Energy Outlook reports. Econ. Policy Energy Environ. 2013, 3, 67-89.

8. Eurobserv'Er Report: Biofuels Barometer; Observ'ER, Paris, France, 2013.

9. OECD-FAO Agricultural Outlook 2013-2022: Highlights; Organisation for Economic Co-operation and Development (OECD): Paris, France, 2013.

10. Yang, F.; Hanna, M.A.; Sun, R. Value-added uses for crude glycerol—A byproduct of biodiesel production. Biotechnol. Biofuels 2012, 5, 13.

11. Nitayavardhana, S.; Khana, S.K. Biodiesel-derived crude glycerol bioconversion to animal feed: A sustainable option for a biodiesel refinery. Bioresour. Technol. 2011, 102, 5808-5814.

12. Thamsiriroj, T.; Murphy, J.D. Can rape seed biodiesel meet the European Union sustainability criteria for biofuels? Energy Fuels 2010, 24, 1720-1730.

13. Nitayavardhana, S.; Khanal, S.K. Innovative biorefinery concept for sugar-based ethanol industries: Production of protein-rich fungal biomass on vinasse as an aquaculture feed ingredient. Bioresour. Technol. 2010, 101, 9078-9085.

14. Yuan, Z.; Xia, S.; Chen, P.; Hou, Z.; Zheng, X. Etherification of biodiesel-based glycerol with bioethanol over tungstophosphoric acid to synthesize glyceryl ethers. Energy Fuels 2011, 25, 3186-3191.

15. Melero, J.A.; van Grieken, R.; Morales, G.; Paniagua, M. Acidic mesoporous silica for the acetylation of glycerol: Synthesis of bioadditives. Appl. Catal. A: Gen. 2008, 346, 44-51. 
16. Li, C.; Lesnik, K.L.; Liu, H. Microbial conversion of waste glycerol from biodiesel production into value-added products. Energies 2013, 6, 4739-4768.

17. Luna, C.; Sancho, E.; Luna, D.; Caballero, V.; Calero, J.; Posadillo, A.; Verdugo, C.; Bautista, F.M.; Romero, A.A. Biofuel that keeps glycerol as monoglyceride by 1,3-selective ethanolysis with pig pancreatic lipase covalently immobilized on $\mathrm{AlPO}_{4}$ support. Energies 2013, 6, 3879-3900.

18. Mota, C.J.A.; da Silva, C.X.A.; Rosenbach, N., Jr.; Costa, J.; da Silva, F. Glycerin derivatives as fuel additives: The addition of glycerol/acetone ketal (solketal) in gasolines. Energy Fuels 2010, 24, 2733-2736.

19. Melero, J.A.; Vicente, G.; Morales, G.; Paniagua, M.; Moreno, J.M.; Roldán, R.; Ezquerro, A.; Pérez, C. Acid-catalyzed etherification of bio-glycerol and isobutylene over sulfonic mesostructured silicas. Appl. Catal. A 2008, 346, 44-51.

20. Beatrice, C.; di Blasio, G.; Lazzaro, M.; Canilla, C.; Bonura, G.; Frusteri, F.; Asdrubali, F.; Baldinelli, G.; Presciutti, A.; Fantozzi, F.; et al. Technologies for energetic exploitation of biodiesel chain derived glycerol: Oxy-fuels production by catalytic conversion. Appl. Energy 2013, 102, 63-71.

21. Eaton, S.J.; George, N.H.; Kimball, R.W.; Smith, J.A.; Pilot, K.A.; Kuflik, M.T.; Bullard, J.M. Formulation and combustion of glycerol-diesel fuel emissions. Energy Fuels 2014, 28, 3940-3947.

22. Lovestead, T.M.; Bruno, T.J. Comparison of diesel fuel oxygenate additives to the compositionexplicit distillation curve method. Part 3: $t$-Butyl glycerols. Energy Fuels 2011, 25, 2518-2525.

23. Di Serio, M.; Casale, L.; Tesser, R.; Santacesaria, E. New process for the production of glycerol tert-butyl ethers. Energy Fuels 2010, 24, 4668-4672.

24. Frusteri, F.; Cannilla, C.; Bonura, G.; Frusteri, L. Glycerol etherification with TBA: High yield to poly-ethers using a membrane assisted batch reactor. Environ. Sci. Technol. 2014, 48, 6019-6026.

25. Cheng, J.K.; Lee, C.L.; Jhuang, Y.T; Ward, J.D.; Chien, I.L. Design and control of glycerol tertiary butyl ethers process for the utilization of a renewable resource. Ind. Eng. Chem. Res. 2011, 50, $12706-12716$.

26. Quispe, C.A.G.; Coronado, C.J.R.; Carvalho, J.A., Jr. Glycerol: Production, consumption, prices, characterization and new trends in combustion. Renew. Sustain. Energy Rev. 2013, 27, 475-493.

27. Rahmat, N.; Abdullah, A.Z.; Mohamed, A.R. Recent progress on innovative and potential technologies for glycerol transformation into fuel additives: A critical review. Renew. Sustain. Energy Rev. 2010, 14, 987-1000.

28. Cherubini, F.; Strømman, A.H. Life cycle assessment of bioenergy systems: State of the art and future challenges. Bioresour. Technol. 2011, 102, 437-451.

29. Malça, J.; Freire, F. Life cycle of Biodiesel in Europe: A review addressing the variability of results and modeling issue. Renew. Sustain. Energy Rev. 2011, 15, 338-351.

30. Nanaki, E.A.; Koroneos, C.J. Comparative LCA of the use of biodiesel, diesel and gasoline for transportation. J. Clean. Prod. 2012, 20, 14-19.

31. González-García, S.; Moreira, M.T.; Feijoo, G.; Murphy, R.J. Comparative life cycle assessment of ethanol production from fast-growing wood crops (black locust, eucalyptus and poplar). Biomass Bioenergy 2012, 39, 378-388. 
32. Grillo Renó, M.L.; Silva Lora, E.E.; Escobar Palacio, J.C.; Venturini, O.J.; Buchgeister, J.; Almazan, O. A LCA (life cycle assessment) of the methanol production from sugarcane bagasse. Energy 2011, 36, 3716-3726.

33. Environmental Management_Life Cycle Assessment-Principles and Framework; ISO 14040; International Organization for Standardization (ISO): Geneva, Switzerland, 2006.

34. Environmental Management_Life Cycle Assessment_Requirements and Guidelines; ISO 14044; ISO: Geneva, Switzerland, 2006.

35. Althaus, H.-J.; Hischier, R.; Weidema, B.; Bauer, C.; Doka, G.; Dones, R.; Frischknecht, R.; Hellweg, S.; Jungbluth, N.; Köllner, T.; et al. Implementation of Life Cycle Impact Methods; Ecoinvent Report No.3; Swiss Centre for Life Cycle Inventories: Dübendorf, Switzerland, December 2007.

36. The Eco-Indicator 99 Manual for Designers; Ministry of Housing, Spatial Planning and the Environment: Amsterdam, The Netherlands, 2000.

37. Ecoinvent Database, version 2; Swiss Centre for Life Cycle Inventories: Zürich, Switzerland, 2007.

38. González-García, S.; García-Rey, D.; Hospido, A. Environmental life cycle assessment for rapeseed-derived biodiesel. Int. J. Life Cycle Assess. 2013, 18, 61-76.

39. Life Cycle Inventories of Bioenergy; Ecoinvent Report No. 17; Swiss Centre for Life Cycle Inventories: Zürich, Switzerland, 2007.

40. Vlad, E.; Bilde, C.S. Reactive distillation-A viable solution for etherification of glycerol with tert-butyl alcohol. Chem. Eng. Trans. 2012, 29, 589-594.

41. Frusteri, F.; Frusteri, L.; Cannilla, C.; Bonura, G. Catalytic etherification of glycerol to produce biofuels over novel spherical silica supported Hyflon ${ }^{\circledR}$ catalysts. Bioresour. Technol. 2012, 118, 350-358.

42. Beatrice, C.; di Blasio, G.; Guido, C.; Cannilla, C.; Bonura, G.; Frusteri, F. Mixture of glycerol ethers as diesel bio-derivable oxy-fuel: Impact on combustion and emissions of an automotive engine combustion system. Appl. Energy 2014, 132, 236-247.

43. Kadam, K.L.; Camobreco, V.J.; Glazebrook, B.E.; Forrest, L.H.; Jacobson, W.A.; Simeroth, D.C.; Blackburn, W.J.; Nehoda, K.C. Environmental Life Cycle Implications of Fuel Oxygenate Production from California Biomass; Technical Report; NREL-National Renewable Energy Laboratory: Golden, CO, USA, May 1999.

44. Jungbluth, N. Erdöl, Ecoinvent Report n.6-IV; Swiss Centre for Life Cycle Inventories: Zürich, Switzerland, 2007.

45. Lechón, Y.; Cabal, H.; de la Rùa, C.; Caldés, N.; Santamaría, M.; Sáez, R. Energy and greenhouse gas emission savings of biofuels in Spain's transport fuel. The adoption of the EU policy on biofuels. Biomass Bionergy 2009, 33, 920-932.

(C) 2015 by the authors; licensee MDPI, Basel, Switzerland. This article is an open access article distributed under the terms and conditions of the Creative Commons Attribution license (http://creativecommons.org/licenses/by/4.0/). 